\title{
Mangrove oyster (Crassostrea spp.) (Sacco, 1897) extractivism in Cananéia estuary (São Paulo, Brazil) from 1999 to 2006: capture and management evaluation
}

\author{
Mendonça, JT. ${ }^{\mathrm{a} *}$ and Machado, IC. ${ }^{\mathrm{b}}$ \\ anstituto de Pesca/Secretaria da Agricultura e Abastecimento do Estado de São Paulo, \\ Av. Wladimir Besnard, s/n, Bairro Morro do São João, CP 61, CEP 11990-000, Cananéia, SP, Brazil

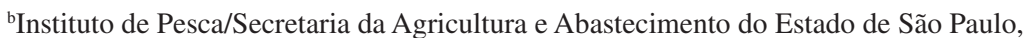 \\ Av. Bartolomeu de Gusmão, 192, CEP11030-906, Santos, SP, Brazil \\ *e-mail: jmendonca@pesca.sp.gov.br \\ Received September 17, 2008 - Accepted December 9, 2008 - Distributed February 28, 2010
}

(With 6 figures)

\begin{abstract}
The oyster Crassostrea spp. is one of the main fisheries resources in the southern portion of São Paulo State. This paper aims to evaluate the extractivism of that resource, supplying subsidies to the implementation of management regulations. This study was developed in Cananéia, from February 1999 to December 2006. The oyster production data in dozens was obtained through weekly or monthly interviews. The annual and average CPUE in dozens per day was analysis to verify significant differences along years. There are no regulations that limit the fishing effort or organize the admission in the fishermen. The admission is controlled by the condition of the market and there is a risk of increasing the fishing effort above the sustainable yield, which demands measures that control the number of fishermen enganged in the activity. Those measures, to be effective, must be created in discussion with the fisheries sector, based on technical information.
\end{abstract}

Keywords: Crassostrea spp., mangrove oyster, CPUE, extractivism, fishery co-management.

\section{O extrativismo da ostra de mangue Crassostrea spp. no estuário de Cananeia (São Paulo, Brasil) de 1999 a 2006: captura e avaliação da gestão}

\section{Resumo}

A ostra do mangue Crassostrea spp. é um dos principais recursos pesqueiros da porção sul do Estado de São Paulo. O presente documento visa avaliar o extrativismo do recurso no município de Cananeia, fornecendo subsídios para implementação de normas de manejo e para a manutenção da sustentabilidade da atividade. $O$ trabalho foi desenvolvido em Cananeia, entre fevereiro de 1999 e dezembro de 2006, com o acompanhamento dos desembarques de ostras junto aos extrativistas profissionais. A produção em dúzias foi obtida por meios entrevistas semanais e/ou mensais. A CPUE (Captura por Unidade de Esforço) anual, em dúzias por dia, foi estimada pela produção total do ano dividida pelo esforço total no ano, e a CPUE anual média foi obtida pela média das CPUEs mensais. Foi aplicada a análise de variância (ANOVA), o teste de Tukey e o teste F para verificação de diferenças significativas entre as CPUEs anuais médias, com $\alpha$ de 5\%. Entre 1999 e 2001 houve queda significativa nos valores de produção e CPUE (anual e anual média), coincidindo com níveis elevados de esforço pesqueiro sobre o recurso. A partir de 2002 os índices de abundância apresentaram estabilização, ocorrendo também diminuição, seguida de estabilização do esforço pesqueiro. A ostra é um recurso de livre acesso, não existindo regulamentação que limite o esforço pesqueiro ou organize o ingresso de pescadores na atividade. $\mathrm{O}$ ingresso é controlado pela condição de mercado do produto, havendo o risco de aumento do esforço de pesca acima do sustentável, o que demanda medidas que controlem o número de pescadores na atividade. Tais medidas, para serem efetivas, devem ser construídas em conjunto com o setor pesqueiro, a partir do subsídio de informações técnicas. Este processo de aprendizado dinâmico tornará mais eficientes às medidas de manejo, com consequente melhora nos resultados de sustentabilidade do recurso, implicando na gestão do recurso de forma integrada, a partir de seus componentes ecológicos, sociais, econômicos e culturais.

Palavras-chave: Crassostrea spp., ostra de mangue, CPUE, extrativismo, comanejo pesqueiro.

\section{Introduction}

The main fishery resources in Brazil have been overexploited for a long time. That situation demands the creation of regulation measures to avoid the collapse of the fisheries. The measures adopted up to now

include fleet limitation, characterisation of fishing gear/ equipment, minimum size of the target species and annual prohibition, known in Brazil as "defeso" (Peres, Pezzuto, Rodrigues, Valentini and Vooren, 2001). Often 
those measures do not accomplish their goal, which is the conservation of fisheries resources.

Artisanal fishery has great social and economic importance for the fishery sector, being responsible for a high number of jobs in coastal communities. According to the Brazilian Institute of the Environment and Renewable Resources (Instituto Brasileiro do Meio Ambiente e dos Recursos Renováveis) - IBAMA (national fisheries manager in Brazil) (IBAMA 1996), artisanal fishery contributes about $56 \%$ of the national seafood production in coastal and offshore waters. From the 25 thousand boats of the national fleet, nearly 23 thousand belong to the artisanal fleet or the small-scale fleet. Due to the difficulties in monitoring that kind of fleet, the values obtained for yield statistics and for the register of the boats are underestimated. The main problem is the existence of different points of distribution of seafood, because this activity, unlike industrial fishery, is scattered along the coast.

The Cananéia, Iguape and Ilha Comprida estuary is inserted into the Lagoon Estuarine system of Cananéia, Iguape and Paranaguá on the south coast of Brazil. Due to its good environmental conservation status, it is nationally and internationally known as the third most productive ecosystem of the South Atlantic, being also part of the Atlantic Forest Biosphere Reserve in 1993 (UNESCO, 2005), and proclaimed a Natural World Patrimony Site for scientific knowledge and the conservation of human values and traditional knowledge based on sustainable development patterns (UNESCO 1999).

There is intense fishery activity, especially artisanal in that system, comprising more than 3,000 fishermen from Iguape, Cananéia and Ilha Comprida cities, and this Lagoon Estuarine System and adjacent coastal area to the main fishery areas (Barreto, Mendonça and Calasans, 2000; Machado, Koga, Woioechovsky and Gelli, 2000; Mendonça and Barbieri, 2001; Mendonça and Katsuragawa, 2001).

One of the main fishery resources on the south coast is the mangrove oyster Crassostrea spp., and the extractivism of this species is the main activity for much of the local population (Besnard, 1949; Wakamatsu, 1971; Akaboshi and Pereira, 1981; Pereira, Galvão and Tanji 1991). Until recently, many authors considered the species Crassostrea rhizophorae and Crassostrea brasiliana as synonyms, because they are very morphologically similar. However, new studies on the two species, using techniques of genetic sequences, show that the species Crassostrea rhizophorae and C. brasiliana are different species, presenting populations genetically structured, with a clear distinction in their stocks distributed on the Brazilian coast (Ignacio, Absher, Lazoski and Solé-Cava, 2000; Lazoski, 2004; Pie, Ribeiro, Boeger, Ostrensky, Falleitos and Angelo, 2006). Although those studies proved the existence of different species, the discussion goes on, and some recent papers identified just one species, called $C$. rhizophorae, occurring in the south and southeast of the Brazilian coast (Varela, Colin,
Schneider, Sampaio, Marques-Silva and Tagliaro 2007). For those reasons, in this paper the species is named mangrove oyster Crassostrea spp.

The preferred substrates of the mangrove oyster are the stilt roots of the red mangrove Rhizophora mangle, and the deep bottom-rocky channels, forming large submerse banks. The species is hermaphrodite, alternating sexes in the same individual, according to environmental conditions (Wakamatsu, 1973; Nascimento, 1978; Bastos, 1997). The oyster feeds on microalgae and organic material in suspension by filtration, and for this reason it develops very well in the high primary productivity environment in Cananéia estuary (Akaboshi et al., 1981). The spatial distribution of the natural banks of oyster Crassostrea spp in the regions occurs from the central part of Cananéia Island, in the south direction up to Cananéia mouth along the coastal line of Cardoso Island (Wakamatsu, 1973). Its density varies according to the hydrographic conditions and substrate. The most productive areas are found around Trapandé Bay, near the mouth of the rivers Itapitangui, Boacica, das Minas and Taquari and on the north side of Ararapira channel (Pereira, Machado, Henriques, Galvão, and Bastos, 2000). In those areas, the communities extract oysters with simple instruments like baskets and sickles. The oyster is sold in different ways: by the dozen (alive, with shells, in natura) or "desmariscada" (raw meat, without shells, in plastic bags) (Campolim and Machado, 1997). The oyster sold by the dozen can be of standard size, called "selected oysters", or it can be sold without standard sizes "in boxes" of about 30 to 50 dozens each. The "desmariscada" and "in boxes" forms are usually for oysters below commercial size, and those are considered predatory practices, even by the extractors. These last two commercial forms also sell for very low prices in commercial transactions.

From the 90's onwards, an interinstitutional project has taught the extractivist communities the "oyster fattening" (Pereira et al., 2000; Campolim and Machado 1997). This activity derived from the technology of integral oyster cultivation developed from the 70's onwards. It consists of the arrangement of adult oysters of about $50 \mathrm{~mm}$ in structures such as "beds" or "trays" in the intertidal zone, until they reach the appropriate size for commercialisation (larger than $70 \mathrm{~mm}$ ). The oyster fattening technique is nowadays employed by nearly 60 oyster extractors in Cananéia estuary, representing approximately two thirds of the active extractors.

That fishery activity has been constantly monitored and evaluated, due to its socioeconomic importance. This paper aims to evaluate oyster Crassostrea spp. extractivism in the Cananéia estuary and so provides a grounding for the protection of the resource and their users, as well as proposing a methodology for the management of this activity.

\section{Materials and Methods}

This study was developed in the south of São Paulo State, in Brazil, in the Cananéia estuary (Figure 1), from 
February 1999 to December 2006, studying the oyster commercial landing from professional extractors.

The yield was obtained via data collection from the extractivists, through weekly and/or monthly interviews. The number of extractivists interviewed was 116, 96, $105,76,66,64,78$ and 71 , respectively in the years from 1999 to 2006. The fluctuation of the number of interviews is firstly due to the difficulties in contacting the registered oyster extractors. Secondly due to the variation in the number of extractors, according to the temporary demand of other more financially attractive production activities.

As the oyster is commercialised by the dozen, and also to make comparison with other references easier, the unit used in the interviews was the dozen. Meanwhile the conversion factor to calculate in kilogrammes is 0.830 (a dozen oysters equals $0.830 \mathrm{~km}$ ).

The Catch per Unit of Effort (CPUE) is widely used as the abundance index in many fisheries in the world (Large, 1992; Freón and Misund, 1999; Gatica and Hernandez, 2003). So, that estimate was chosen as the indicator of the extractivist state of the mangrove oyster in Cananéia estuary. The calculations of the Catch per Unit of Effort, in dozens for days of extractivism, was estimated through the total monthly or annual production, divided by the total effort in hours (or days) of extractivism from all the extractors sampled in the month or the year.

The annual CPUE was estimated from the total annual production divided by the total effort of the year,

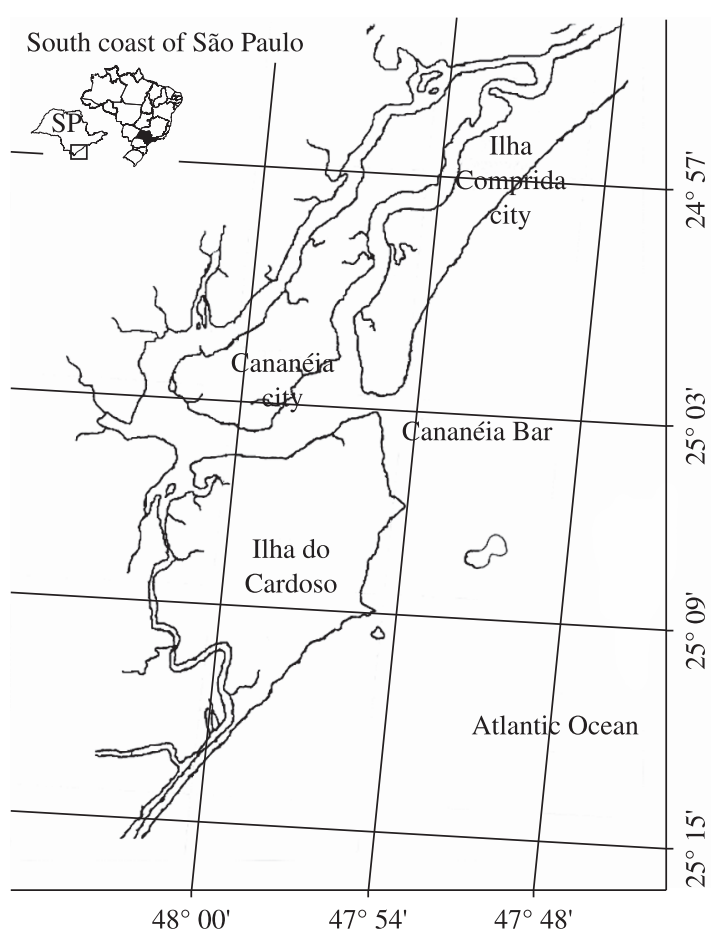

Figure 1. Study area - Cananéia Estuary. and the average annual CPUE was obtained by the average of the monthly CPUEs. The Analysis of Variance (ANOVA) was used to verify the significant differences among the average annual CPUEs, complemented by the Tukey test to indicate in which years occurred the most significant differences, a degree of significance $(\alpha)$ of $5 \%$ (Callegari-Jacques, 2004). Due to the average variation, the logarithm was applied, obtaining the decrease of the ranges of variation. In order to give more dependability to ANOVA, the analyses were complemented by the application of the F-test to verify the significant differences among the annual CPUEs, comparing the tendency line of the annual CPUE, and the zero inclination line to a significance degree $(\alpha)$ de $5 \%$ (Zar, 1999).

From 1999 to 2006, a weekly sampling was conducted in the Cooperostra - Cooperativa dos Produtores de Ostra de Cananéia - a community cooperative, collecting total height data (shell length from the umbo (beak-like projections at the dorsal part of the shell; it is the oldest part of a bivalve shell - to the posterior extremity) in order to observe the average commercial length. The Propesq ${ }^{\circledR}$ data bank (Ávila-Da-Silva et al. 1999) was used to consolidate the biometric and yield data.

\section{Results}

The estimated annual oyster yield in Cananéia in the 70 s was close to 300 tons, i.e., 360 thousand dozen oysters, increasing in the 90's to 600 thousand oyster per year (Campolim and Machado 1997). In the beginning of this study, the registered oyster production reached more than 333 thousand dozens (2000), gradually decreasing to 76 thousand oysters unloaded in 2004, with a small increase in the two last years (Figure 2). Those yield values are, however, just part of the total, as they express the activity of a significant sample from the universe of the extractors in the city. Nevertheless, as it is a historical series from monitoring extraction, it can be concluded that the tendencies relative to increase/decrease of the yield reflect the reality.

Figure 3 shows the average monthly mangrove oyster production unloaded from 1999 to 2006. Oyster ex-

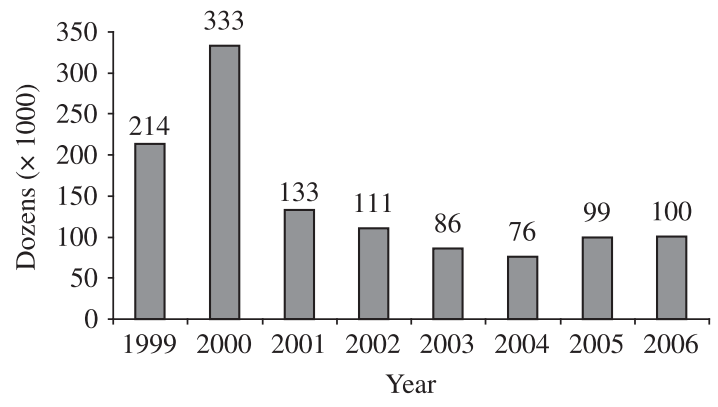

Figure 2. Annual oyster yield in Cananéia, from 1999 to 2006. 
tractivism is more intense in the cold months than in the hot months. In the studied years, in the winter months (from July to September) a mean production of about 14 thousand dozen oysters was recorded, and below 10 thousand dozen oysters in the summer (from January to March). The production recorded in the autumn (from April to June) was between 11 and 14 thousand dozens and in the spring (from October to December), it was of 10 and 13 thousand dozens. This analysis should take into consideration the fact that the supplying of the "oyster fattening" structures and commercialisation below the permitted size ("desmariscada" and "in boxes", i.e that demand a great quantity of the product), occurs especially in the winter. In addition, the annual oyster extractivism prohibition (Order of Sudepe - Superintendence of Development for Fisheries - no 46 December 11, 1987) occurs in the summer, and as the extractivism becomes illegal it tends to decrease. Nevertheless, oyster commercialisation, in dozens from fattening structures or from product storage in the natural environment, tends to increase in the summer.

The studies prove that the monthly CPUE from 1999 to 2006 varied from 8.3 to 45.5 dozen oysters per day (Figure 4). During the studied months, a slight decreasing tendency in the abundance indexes in the summer months was observed.

The annual CPUEs varied from 12.2 to 38.5 dozens per day. The lowest values (12.2 dozens per day) occurred in 2001, and in the other years they were higher than 17 dozens per day (Figure 5). Although 2001 was not the year with the lowest yield of the studied period, it was observed then a drastic fall in the landed production (from 333 thousand dozen oysters in 2002 to 133 thousand dozens in 2001) and the lowest CPUE values (annual and annual average), besides the systematically low values of CPUE, with decreasing tendency (Figure 5).

The fishery effort data (Figure 6) show that from 2000 and 2001 the effort remained high, decreasing from 2002 onwards, with a slight improvement on CPUE values from 2003 onwards. Nevertheless an increase of the production values was observed only from 2005 (Figure 2). There was a significant difference among the annual average CPUEs $(p=0.05)$ found in eight years of study, confirmed by the Tukey test for practically all the

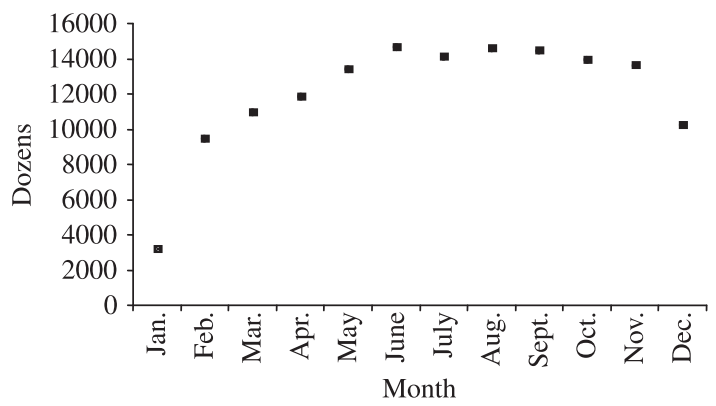

Figure 3. Average monthly mangrove oyster production unloaded from 1999 to 2006. years, specially for the first years of study (1999; 2000; 2001) and in the remaining years, there was a significant decrease in productivity. Significant differences were not observed in 2002; 2003; 2004; 2005 and 2006 (Table 1). The application of the F-test showed an inclination significantly equal to zero $(\mathrm{p}<0.05)$. There were not significant differences among the annual CPUEs pointing to a possible stability in the catches over all the years. This fact is due to the probable recuperation of the CPUE in the last years of the studies.

During the studied period of the mangrove oyster (1999 to 2006), a remarkable decreasing in fishery effort was observed, in number of hours, abruptly decreasing from 2001 to 2002 . In the following years the effort kept stable around 8.8 thousand days (Figure 6).

The average height of the 13225 specimens of Crassostrea spp. measured at Cooperostra was $7.7 \mathrm{~cm}$. As Cooperostra commercialises the oyster to order in

Table 1. Tukey test to verify significant differences among the average annual CPUEs, with $\alpha$ of 5\% from 1999 to 2006 of mangrove oyster, where q: " $q$ " test; critical value $=4.423$. (*) Significant differences

\begin{tabular}{crcl}
\hline Years & \multicolumn{1}{c}{$\mathbf{q}$} & Significance & \multicolumn{1}{c}{ P } \\
\hline $1999-2000$ & 6.062 & $* *$ & $\mathrm{P}>0.01$ \\
$1999-2001$ & 10.373 & $* * *$ & $\mathrm{P}>0.001$ \\
$1999-2002$ & 4.210 & $\mathrm{~ns}$ & $\mathrm{P}>0.05$ \\
$1999-2003$ & 5.022 & $*$ & $\mathrm{P}>0.05$ \\
$1999-2004$ & 4.413 & $\mathrm{~ns}$ & $\mathrm{P}>0.05$ \\
$1999-2005$ & 1.722 & $\mathrm{~ns}$ & $\mathrm{P}>0.05$ \\
$1999-2006$ & 3.929 & $\mathrm{~ns}$ & $\mathrm{P}>0.05$ \\
$2000-2001$ & 17.910 & $* * *$ & $\mathrm{P}>0.001$ \\
$2000-2002$ & 11.194 & $* * *$ & $\mathrm{P}>0.001$ \\
$2000-2003$ & 11.696 & $* *$ & $\mathrm{P}>0.001$ \\
$2000-2004$ & 11.414 & $* * *$ & $\mathrm{P}>0.001$ \\
$2000-2005$ & 8.482 & $* *$ & $\mathrm{P}>0.001$ \\
$2000-2006$ & 10.712 & $* * *$ & $\mathrm{P}>0.001$ \\
$2001-2002$ & 6.716 & $* * *$ & $\mathrm{P}>0.001$ \\
$2001-2003$ & 5.295 & $* *$ & $\mathrm{P}>0.01$ \\
$2001-2004$ & 6.496 & $* * *$ & $\mathrm{P}>0.001$ \\
$2001-2005$ & 9.428 & $* * *$ & $\mathrm{P}>0.001$ \\
$2001-2006$ & 6.767 & $* * *$ & $\mathrm{P}>0.001$ \\
$2002-2003$ & 1.077 & $\mathrm{~ns}$ & $\mathrm{P}>0.05$ \\
$2002-2004$ & 0.221 & $\mathrm{~ns}$ & $\mathrm{P}>0.05$ \\
$2002-2005$ & 2.712 & $\mathrm{~ns}$ & $\mathrm{P}>0.05$ \\
$2002-2006$ & 0.212 & $\mathrm{~ns}$ & $\mathrm{P}>0.05$ \\
$2003-2004$ & 0.868 & $\mathrm{~ns}$ & $\mathrm{P}>0.05$ \\
$2003-2005$ & 3.649 & $\mathrm{~ns}$ & $\mathrm{P}>0.05$ \\
$2003-2006$ & 1.255 & $\mathrm{~ns}$ & $\mathrm{P}>0.05$ \\
$2004-2005$ & 2.932 & $\mathrm{~ns}$ & $\mathrm{P}>0.05$ \\
$2004-2006$ & 0.428 & $\mathrm{~ns}$ & $\mathrm{P}>0.05$ \\
$2005-2006$ & 2.434 & $\mathrm{~ns}$ & $\mathrm{P}>0.05$ \\
\hline & & &
\end{tabular}


1999
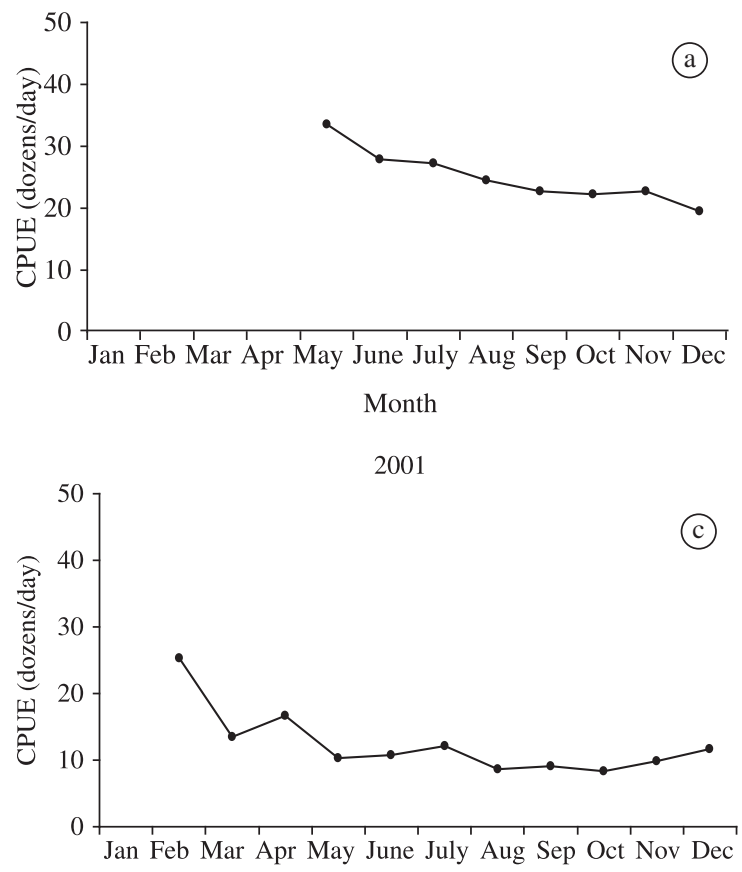

Month

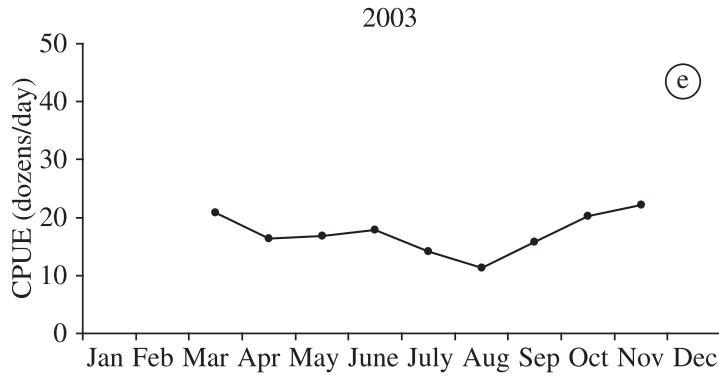

Month

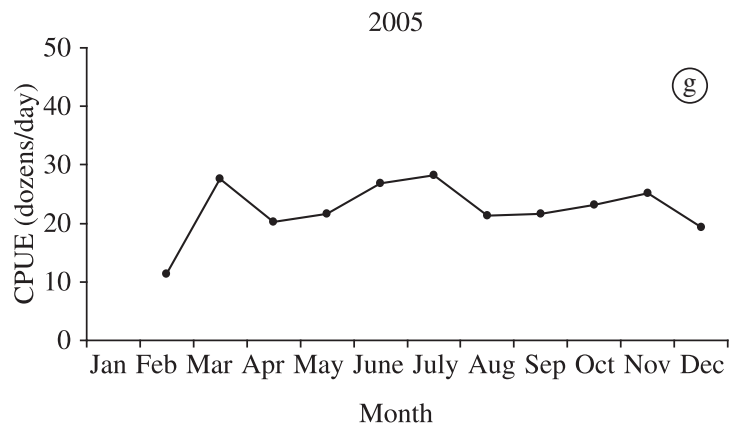

2000
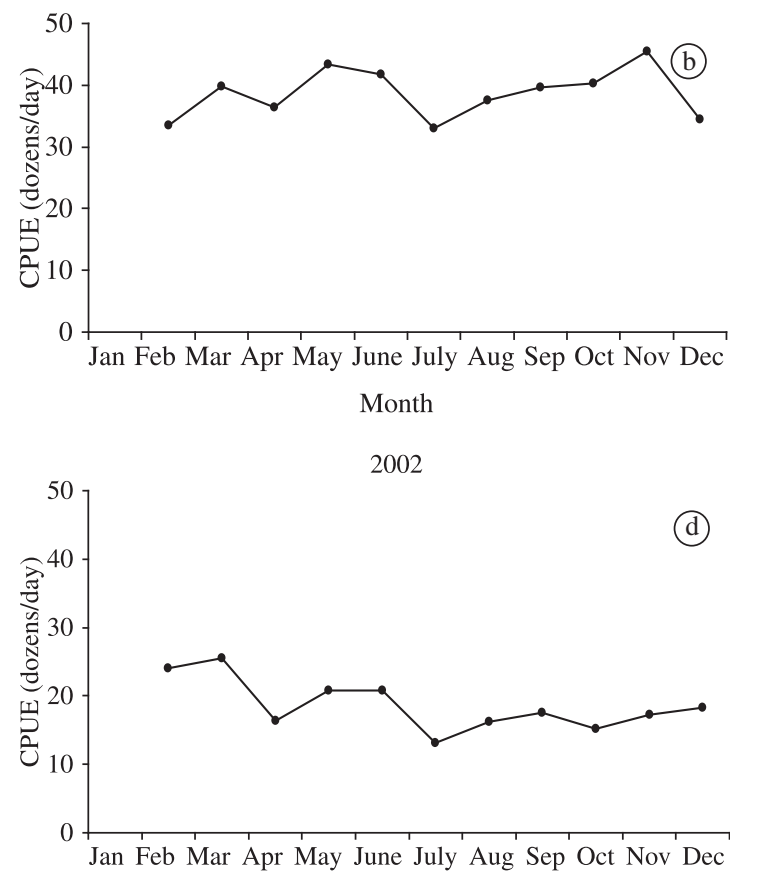

Month

2004

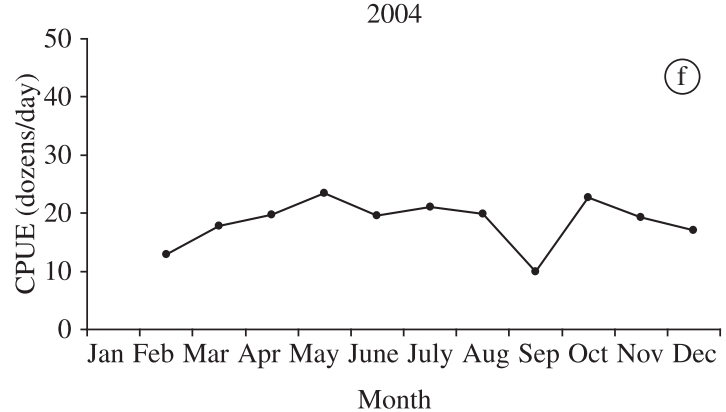

2006

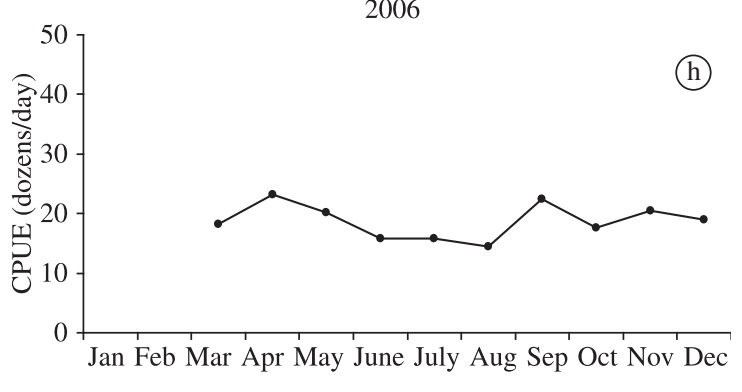

Month

Figure 4. Catch per unit of effort (dozens/day) monthly from 1999 to 2006.

pattern sizes (small, medium or large, respectively from five to six, from seven to eight and above eight centimetres), this measurement merely expresses the commercial pattern of Cooperostra, and does not represent the average size of all the oysters extracted and commercialised in Cananéia.
The persistent illegal commercialisation of the product, especially below the permitted size (five centimetres) demands measures of order and management. The kinds of presentation "desmariscada" and "in boxes", if it is confirmed that they use oysters below the permitted size, should be an object of caution, even more consider- 


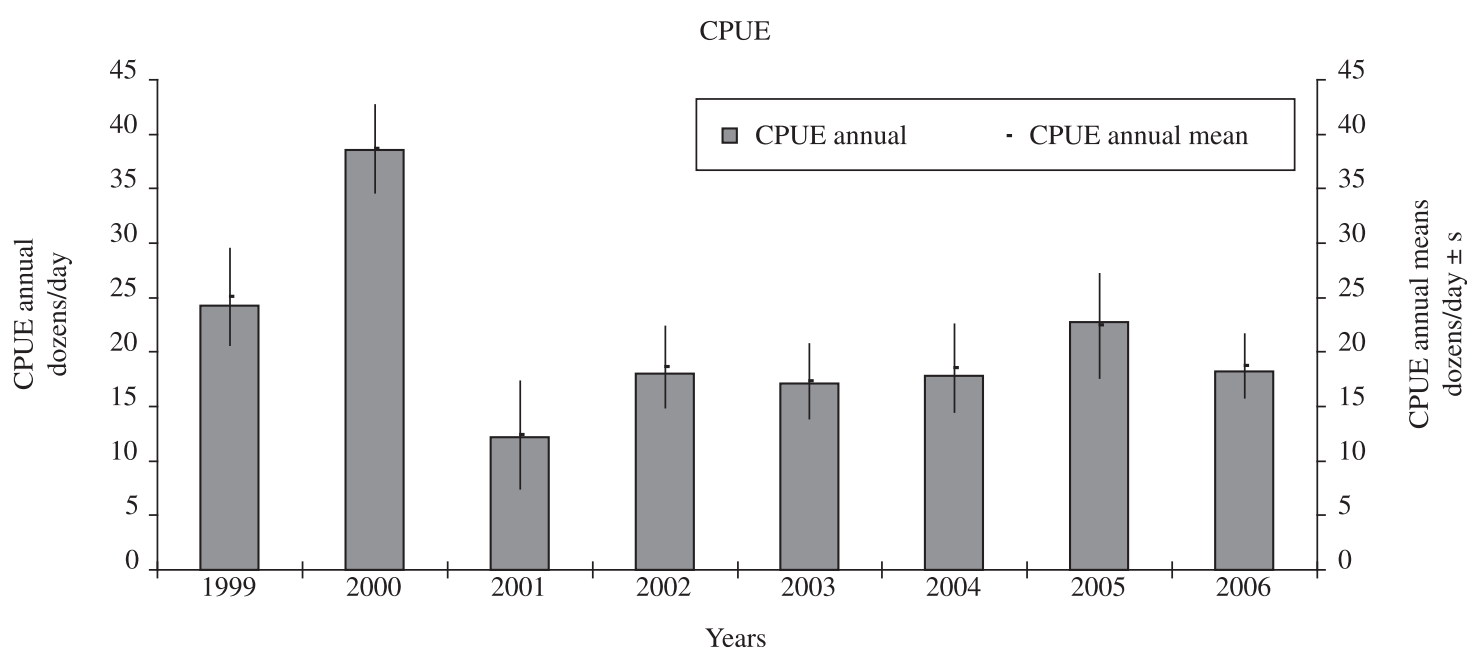

Figure 5. Average annual and annual mangrove oyster catch per unit of effort (dozens/day), from 1999 to 2006.

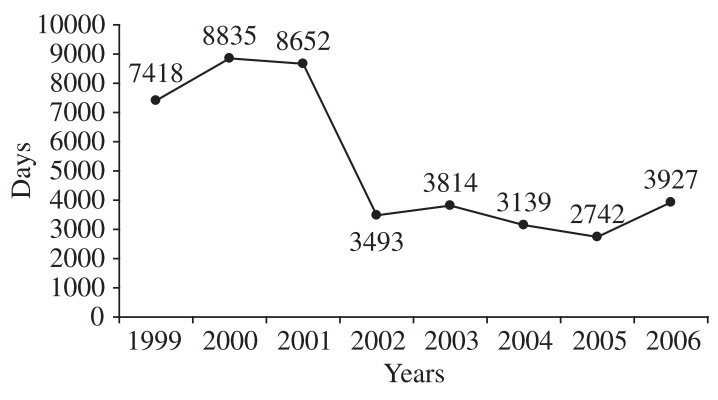

Figure 6. Annual fishery effort (in days) of mangrove oyster extract, from 1999 to 2006.

ing that they get low prices, and demand large quantities of oysters to obtain a minimum income.

\section{Discussion}

\subsection{Evaluation of the catch}

It has been estimated that in the 90's, there existed 100 oyster and other clam producers in Cananéia city (Campolim and Machado 1997). Many of them did not have this activity as their main source of income. Recently a census in the region registered 88 oyster extractors in Cananéia city, estimating at about 100 the number of active extractors in the region (Machado, I.C. 2009). In this paper, the lower annual number of oyster extractors interviewed for the yield and effort data collection was 64 (2004), so it can thereby be stated that sampling has always been significant regarding the number of extractors estimated for the city. Pereira et al. (2000) and Pereira, Machado, Henriques, Galvão and Yamanaka (2001) estimated for the whole Cananéia mangrove a stock of 16 million dozen oysters, 1.5 million of these being of commercial size, considering the existent banks on the margins of the channels, rivers and "gamboas" (chan- nels dependent on flow tide, without their own source). In 2003, it was indicated that the maximum sustainable extraction was around 788 thousand dozen oysters per year, if the natural oyster banks were kept at the level of 16 million dozens (Pereira, Henriques, and Machado 2003). The values of annual production found in this paper were much lower than the maximum sustainable extraction of commercial oysters estimated by (Freón and Misund 1999). But in the analysis of this information, it must be considered that the production data were partial, possibly underestimating the total annual production of the city, but faithful to the general tendency of increase and decrease over time. With this approach, the CPUE data can be considered as an additional index of the situation of the resource.

From 2001 onwards, the index of abundance (CPUE) showed a significant decrease. In 2002, the production became stable: close to 20 dozens per day, reaching up to 100 thousand oysters per year. That reduction can indicate that the extraction was above the sustainable exploration of the stock, i.e. that the oyster banks possibly did not become stable as estimated (Pereira et al., 2000; 2001).

The hypothesis of stock reduction of the mangrove oyster in Cananéia estuary is in consonance with the extractivism techniques and commercialisation of oysters below the minimum size permitted $(<5 \mathrm{~cm})$, possibly causing impacts in the population structure of the resource.

The reduction of fishery effort that occurred from 2002 onwards corresponded to a small increase in the abundance indexes, with discrete evidence of recuperation of the resource. Usually, when the abundance of the resource shows some improvement, fishery effort is quickly intensified, but when abundance decreases, fishery effort takes time to decrease, causing negative impacts on the stocks and in the economy (Steele and Hoagland, 2003). Concerning the mangrove oyster, fish- 
ery effort showed a rapid decrease, especially because of the commercial limitations of the product, which contributed to the interruption of resource stock depletion.

\subsection{Activity management}

The purpose of fishery activity monitoring is to lead the decisions-making process and also implement the rules that aim to maintain the resources to the minimum level to survival of the fisheries activity (Sumaila, 2001; Policansky, 2001; Haggan, 2001).

Data and information are the basis for good management, being behind all the stages of administration of fishery resources, including the politics for elaboration, management plans, evaluation of the process, the updating policies and the continuity of the process (FAO Fisheries Department 2003). One of the difficulties found in fishery monitoring is the data collection from the extractivists, since frequently these data do not have much quality and precision. In order to solve those problems, the information must be carefully checked and refined, so that only consistent information is used.

In 2004, the potential limitations of the conventional monitoring methods for the studied populations were raised, emphasising that a complete independence between CPUE and stock density is rare, but there is not a linear and direct relation between them (Moller, Berkes, Lyver and Kislalioglu, 2004). The lack of conventional patterns for the management of fishery resources has been much discussed, the use of linear patterns being inadequate (Berkes, Colding and Folke, 2003). So the use of qualitative analysis is necessary as a complement to the quantitative, as well as the approach in multiplicity of perspectives for the conduction of non-linear complex systems. The choice of a direction for fishery management is eminently qualitative, although quantitative information cannot be disregarded (Berkes, Mahon, Mcconney, Pollnac and Pomeroy, 2001).

One of the techniques of management that has been largely used is co-management, that was defined by Jentoft (Jentoft, Mccay and Wilson 1998) as the process of cooperation and participation in the decisions for regulation performed by groups of users, governmental agents and research institutions. It is a current belief that the involvement of the community, included in the management process, offers the fishery communities an efficient recovery and the control of their means of livelihood (Schreiber, 2001). According to Domínguez-Torreiro (Domínguez-Torreiro, Freijeiro-Álvarez, and IglesiasMalvido, 2004), the involvement of the users in fishery policies helps to obtain a higher economic efficiency in the exploitation of resources. In a general way, the fishermen agreed that there is an excessive effort in fishery activity and that management actions help sustain the way of life of artisanal fishery. When people do not use scientific knowledge and local community knowledge as complementary sources of information, or disregard the second, the tendency is to impose rules out of the context. So, those rules, as illegitimate, will be continuously disrespected, and this can be the reason for the artisanal fishery crisis (Boisneau and Mennesson-Boisneau, 2001; Schreiber, 2001; Paolisso, 2002). According to Moraes (Moraes, 2004), legislation can easily prohibit, but hardly promotes management, in such a way that legal instruments like zoning, laws and decrees are necessary, but not sufficient.

\subsection{Proposals for mangrove oyster extractivism management}

The studied region is one of the most conserved in São Paulo state. This does not occur in other productive places, becoming the main management problem of estuarine fisheries (Severino-Rodrigues, Pita and GraçaLopes 2001; Schreiber, 2001; Paolisso, 2002). However, the decrease in the abundance index from 2000 and 2001 points to a threat to the resource, mainly by the fishing effort being above the sustainable level, requiring measures to maintain sustainability. In the following years, until 2006, the reduction of fishery effort occurred in an indirect way, through market regulation. This external limitation forced the fishermen to decrease their effort over the resource. This fact also occurs in other fishery activities of the region, such as with iriko fisheries, in the Enseada da Baleia and Vila Rápida communities (Cardoso and Nordi, 2006).

According to Vetemaa et al. (Vetemaa, Vaino, Saat and Kuldin, 2001) the situation of the stock of a fisheries resource is the counterbalance between abundance of the resource, extractivist practice and number of fishermen.

Since the decrease of oyster extractivism in the Cananéia estuary is not related to the loss of the productive capacity of the environment, usually caused by environmental degradation, management actions should be focused, at the present moment, on the extractivist practices and on the control of the number of users of the resource. With that purpose, actions and regulations that inhibit the commercialisation of oysters below commercial size, or providing alternatives like oyster fattening, meet the stock conservation goals, and guarantee sustainable extractivism (Campolim and Machado, 1997; Pereira et al., 2001).

Measures aimed at fishery effort control, the socioeconomic sustainability of the activity and ecological sustainability of the resource are essential, because the market logic is very instable, and can even stimulate an increase in fishery effort. In that sense, the granting of specific fishery permits, by cadastres, could work like a tool for controlling the admission of new extractivists, who when following market demands, tend to increase pressure on the resource, threatening its sustainability.

In addition, participative co-management would increase the efficiency of actions related to extractivist practices and the control of the number of users. Those measures would decrease conflicts and give legitimacy to the process, promoting the management of the resource in a sustainable way. 


\section{Conclusions}

the extractivism of the mangrove oyster in Cananéia estuary is more intense in the cold months than in the hot months. So in the winter there is an increase of oyster extraction for commercialisation "desmariscada" (raw, without shells) and "in boxes", that demand large quantities of oysters. Furthermore, annual prohibition of oyster extraction ("defeso") occurs in the summer, from December to February.

The mangrove oyster CPUE severely declined from 1999 to 2001, which coincides with a decrease in production, indicating impacts of extractivism on the resource population structure. The abundance index tended to stabilise from 2002 onwards, when the fishing effort also stabilised at a lower level. A discrete evidence of recovery of the resource, observed through the increase of the abundance indexes, corresponded to the reduction of fishery effort, which occurred from 2002.

At present, management actions for mangrove oyster extractivism in Cananéia estuary should be concentrated on the inhibition of predatory extractivism and search for alternative practices, and on the control of the number of users of the resource. The use of the concept of participative co-management would increase the efficiency of such management actions.

\section{References}

AKABOSHI, S. and PEREIRA, OM., 1981. Ostreicultura na região lagunar estuarina de Cananéia, São Paulo, Brasil. I Captação de Larvas de ostras Crassostrea brasiliana (Lamarck, 1819) em ambiente natural. Boletim do Instituto de Pesca, vol. 8, p. 87-104.

ÁVILA da SILVA, AO., CARNEIRO, MH. and FAGUNDES, L., 1999. Gerenciador de banco de dados de controle estatístico de produção pesqueira marítima. In Anais do 11 Congresso Brasileiro de Engenharia de Pesca e 1 Congresso Latino Americano de Engenharia de Pesca. Recife. p. 824-832. (vol. 2).

BARRETO, W., MENDONÇA, JT. and CALASANS, GC., 2000. Caracterização das capturas de siri-azul Callinectes ssp. no litoral sul do Estado de São Paulo em 2000. In Anais da 13 Semana Nacional de Oceanografia. Itajaí: UNIVALI/ FACIMAR. p. 515-516. (vol. 1).

BASTOS, AA., 1997. A coleta de ostra Crassostrea brasiliana e manejo sustentado em áreas de manguezal (Mandira Cananéia). São Paulo: Universidade de São Paulo. 98 p. [Dissertação de Mestrado].

BERKES, F., MAHON, R., MCCONNEY, P., POLLNAC, RC. and POMEROY, RS., 2001. Managing small-sale fisheries: alternative directions and methods. Ottawa, Canada: International Development Research Centre. Ottawa, Canada. p. 309.

BERKES, F., COLDING, J. and FOLKE, C., 2003. Navigating social ecological systems: building resilience for complexity and change. Cambridge: Cambridge University. 393 p.
BESNARD, W., 1949. A ostra da região de Cananéia. São Paulo: Secretaria da Agricultura do Estado de São Paulo. p. 1-6. (Relatório sobre o estudo das ostras de Cananéia- SP).

BOISNEAU, P. and MENNESSON-BOISNEAU, C., 2001. Inland commercial fisheries management. Fisheries Management and Ecology, vol. 8, no. 4-5, p. 303-310.

CALLEGARI-JACQUES, SM., 2004. Bioestatística: princípios e aplicações. Porto Alegre: Artmed. 255 p.

CAMPOLIM, MB. and MACHADO, IC., 1997. Proposta de ordenamento da exploração da ostra do mangue Crassostrea brasiliana na região estuarina-lagunar de Cananéia-SP, com vistas à sustentabilidade do recurso. In Anais do Seminário Ciência e Desenvolvimento Sustentado. São Paulo, USP. p. $153-155$.

CARDOSO, TA. and NORDI, N., 2006. Small-scale manjuba fishery around Cardoso Island State Park, SP, Brazil. Revista Brasileira de Biologia = Brazilian Journal of Biology, vol. 66, no. 4, p. 963-973.

DOMÍNGUEZ-TORREIRO, M., FREIJEIRO-ÁLVAREZ, AB. and IGLESIAS-MALVIDO, C., 2004. Co-management proposals and their efficiency implizarions in fisheries management: the case of the Grand Sole fleet. Marine Policy, vol. 28 , no. 3 , p. $213-219$.

Food and Agriculture Organization - FAO, 2003. The ecosystem approach to fisheries. Rome: FAO Technical Guidelines for Responsible Fisheries. 112 p. (no. 4, suplemento 2)

FREÓN, P. and MISUND, OA., 1999. Dinamics of pelagic fish distribution and begaviour: effects on fisheries and stock assessment. Oxford: Blackwell Science. 348 p.

GATICA, C. and HERNANDEZ, A., 2003. Tasas de captura estandarizadas como índice de abundância relativa en pescarías: enfoque por Modelos Lineares Generalizados. Investigaciones marinas., vol. 31, no. 2, p. 107-115.

HAGGAN, N., 2001. Reinventing the tree: reflection on the organic growth and creative pruning of fisheries management structures. In PITCHER, TJ., HART, PJB. and PAULY, D. (Eds.). Reinventing Fisheries Manangement. Dordrecht, Netherlands: Kluwer Academic Publishers. p. 19-30. (no. 2, parte 1). Instituto Brasileiro do Meio Ambiente e dos Recursos Naturais Renováveis - IBAMA, 1996. Diagnóstico da pesca marítima do Brasil. Brasília 163 p. (Coleção Meio Ambiente/ Série estudos de pesca, no. 20).

IGNACIO, BL., ABSHER, TM., LAZOSKI, C. and SOLÉCAVA, AM., 2000. Genetic evidence of the presence of two species of Crassostrea (Bivalvia: Ostreidae) on the coast of Brazil. Marine Biology, Londres. Vol. 136, no. 6, p. 987-991.

JENTOFT, S., MCCAY, B. and WILSON, DC., 1998. Social theory and fisheries co-management. Marine Policy, vol. 22, no. $4 / 5$, p. $423-436$.

LARGE, PA., 1992. Use of multiplicative model to estimate relative abundance from commercial CPUE data. ICES Journal Marine Science., vol. 49, no. 3, p. 253-261.

LAZOSKI, CVS., 2004. Sistemática molecular e genética populacional de ostras brasileiras (Crassostrea spp.). Rio de Janeiro: Universidade Federal do Rio de Janeiro. 145 p. [Tese de Doutorado]

MACHADO, IC., KOGA, SM., WOIOECHOVSKY, E. and GELLI, DS., 2000. Estudo da ocorrência de contaminação 
orgânica no estuário de Cananéia-SP, Brasil, como subsídio para a extração, manejo e cultivo da ostra de mangue Crassostrea brasiliana. 1. Avaliação da qualidade da água. Higiene Alimentar, vol. 14, no. 72, p. 66-75.

MACHADO, I.C. 2009. Um retrato do extrativismo: a sustentabilidade na exploração comercial da ostra de mangue em Cananéia-SP. Tese de doutorado. Programa de PósGraduação em Ecologia e Recursos Naturais da Universidade Federal de São Carlos. São Carlos, 144p

MENDONÇA, JT. and BARBIERI, E., 2001. A pesca do siri no litoral do Estado de São Paulo. Cadernos do Centro Universitário São Camilo, vol. 7, no. 2, p. 36-46.

MENDONÇA, JT. and KATSURAGAWA, M., 2001. Caracterização da pesca artesanal no complexo estuarinolagunar de Cananéia-Iguape, Estado de São Paulo, Brasil (19951996). Acta Scientiarum, vol. 23, no. 2, p. 535-547.

MOLLER, HF., BERKES, F., LYVER, PO. and KISLALIOGLU, M., 2004. Combining science and tradicional ecological Knowledge: monitoring populations for co-management. Ecology and Society, vol. 9, no. 3. p. 2.

MORAES, MBR., 2004. Área de Proteção Ambiental como agência de desenvolvimento sustentável: APA Cananéia - Iguape - Peruíbe/SP. São Paulo: Annablume/FAPESP. 146 p.

NASCIMENTO, I., 1978. Reprodução da ostra de mangue Crassostrea rhizophorae um subsídio ao cultivo. São Paulo: Universidade de São Paulo. 200 p. [Tese de Doutorado].

Organização das Nações Unidas para a Educação, a Ciência e a Cultura - UNESCO, 1999. World Heritage Nomination: UCN Technical Evaluation Atlhantic Forests (southeast) Brazil. Marrakesh, Morocco. p. 1-8.

Organização das Nações Unidas para a Educação, a Ciência e a Cultura - UNESCO, 2005. World Network of Biosphere Reserves: SC/EES. Marrakesh, Morocco. The MAB Program. $19 \mathrm{p}$.

PAOLISSO, M., 2002. Blue crabs and controversy on the Chesapeake bay: A cultural model for understanding watermen's reasoning about blue crab management. Human Organization, vol. 61 , no. 3, p. 226-239.

PEREIRA, OM., GALVÃO, MSN. and TANJI, S., 1991. Época e método de seleção de sementes de ostra Crassostrea brasiliana (Lamarck, 1819) no complexo estuarino-lagunar de Cananéia, estado de São Paulo $\left(25^{\circ} \mathrm{S} ; 48^{\circ} \mathrm{W}\right)$. Boletim do Instituto de Pesca, vol. 18, p. 41-49.

PEREIRA, OM., MACHADO, IC., HENRIQUES, MB., GALVÃO, MSN. and BASTOS, AA., 2000. Avaliação do estoque da ostra Crassostrea brasiliana (LAMARCK, 1819) em bosques de manguezal da região estuario-lagunar de Cananéia $\left(025^{\circ} \mathrm{S} ; 048^{\circ} \mathrm{W}\right)$. Boletim Técnico do Instituto de Pesca, vol. 26, no. 1, p. 17-35.

PEREIRA, OM., MACHADO, IC., HENRIQUES, MB., GALVÃO, MSN. and YAMANAKA, N., 2001. Avaliação do estoque da ostra Crassostrea brasiliana (Lamarck, 1819) em bosques de manguezal de rios e gamboas do complexo estuarino-lagunar de Cananéia. Boletim do Instituto de Pesca, vol. 27 , no. 1 , p. $85-95$.
PEREIRA, OM., HENRIQUES, MB. and MACHADO, IC., 2003. Estimativa da curva de crescimento da ostra Crassostrea brasiliana em bosques de mangue e proposta para sua extração ordenada no estuário de Cananéia, SP, Brasil. Boletim do Instituto de Pesca, vol. 29, no.1, p. 19-28.

PERES, JAA., PEZZUTO, PR., RODRIGUES, LF., VALENTINI, H. and VOOREN, CM., 2001. Relatório da reunião técnica de ordenamento da pesca de arrasto nas regiões sudeste e sul do Brasil. Notas Técnicas FACIMAR, vol. 5, p. $1-34$.

PIE, MR., RIBEIRO, RO., BOEGER, WA., OSTRENSKY, A., FALlEITOS, RM. and ANGELO, L., 2006. Short communication a simple PCR-RFLP method for the discrimination of native and introduced oyster species (Crassostrea brasiliana, C. rhizophorae and C. gigas; Bivalvia: Ostreidae) cultured in Southern Brazil. Aquaculture Research, vol. 37 , no. 15 , p. $1598-1600$.

POLICANSKY, D., 2001. Science and decision making in fisheries management. In PITCHER, TJ., HART, PJB. and PAULY, D. (Eds.). Reinventing Fisheries Manangement. Dordrecht, Netherlands: Kluwer Academic Publishers. p. 57-72. (no. 4, parte 2).

SCHREIBER, D., 2001. Co-management without involvement: the plight of fishing communities. Fish and Fisheries, vol. 2, no. 4, p. 376-384.

SEVERINO-RODRIGUES E., PITA, JB. and GRAÇA-LOPES, R., 2001. Pesca artesanal de siris (Crustacea, Decapoda, Portunidade) na Região estuarina-lagunar de Santos e São Vicente, Brasil. Boletim do Instituto de Pesca, vol. 27, no. 1, p. 7-19.

STEELE, J. and HOAGLAND, P., 2003. Are fisheires "sustainable"? Fisheries Research, vol. 64, no.1, p. 1-3.

SUMAILA, UR., 2001. Protect marine reserves as hedges against uncertainty: an economist's perspective. In PITCHER, TJ., HART, PJB. and PAULY, D. (Eds.). Reinventing Fisheries Manangement. Dordrecht, Netherlands: Kluwer Academic Publishers. p. 303-310. (no. 23, parte 4).

VARELA, ES., COLIN, RB., SCHNEIDER, H., SAMPAIO, I., MARQUES-SILVA, NS. and TAGLIARO, CH., 2007. Molecular phylogeny os mangrove oysters (Crassostrea) from Brazil. Journal of Molluscan Studies Advance Access, vol. 73, p. 229-234.

VETEMAA, M., VAINO, V., SAAT, T. and KULDIN, S., 2001. Co-operative fisheries management of the cross border Lake Peipsi-Pihkva. Fisheries Management and Ecology, vol. 8, no. 4-5, p. 443-451.

WAKAMATSU, T., 1971. Nota sobre as possibilidades de ostreicultura na baía de Cananéia (Estado de São Paulo, Brasil). Rio de Janeiro: Comision Asesora Regional de Pesca para el Atlântico Sudoccidental. p. 1-29. (Documentos Técnicos, no. 28)

WAKAMATSU, T., 1973. A ostra de Cananéia e seu cultivo. São Paulo: SUDELPA. 141 p.

ZAR, JH., 1999. Biostatisticall analysis. 4 ed. New Jersey: Prentice Hall. 929 p. 